\title{
The impact of a biomanipulation experiment on the ichthyofauna diet from a neotropical reservoir in Brazilian semiarid
}

\author{
O impacto de um experimento de biomanipulaçáo na dieta da ictiofauna de um \\ reservatório do semiárido neotropical
}

\section{Cristiane de Carvalho Ferreira Lima Moura ${ }^{1 *}$, Jônnata Fernandes Oliveira ${ }^{1}$,}

José Luís Costa Novaes ${ }^{1}$, Rodrigo Silva da Costa $^{1}$, Darlan Dantas Alves de Araújo ${ }^{1}$ and Danielle Peretti ${ }^{2}$

${ }^{1}$ Laboratório de Ecologia de Peixes \& Pesca Continental, Departamento de Ciências Animais,

Universidade Federal Rural do Semiárido - UFERSA, BR 110, Km 47, Costa e Silva,

CEP 59625-900, Mossoró, RN, Brasil

${ }^{2}$ Laboratório de Ictiologia, Departamento de Ciências Biológicas, Universidade do Estado do Rio

Grande do Norte - UERN, Av. Prof. Antônio Campos, Costa e Silva, CEP 59625-620,

Mossoró, RN, Brasil

*e-mail: cristianecarvalho@ufersa.edu.br

Cite as: Moura, C.C.F.L. et al. The impact of a biomanipulation experiment on the ichthyofauna diet from a neotropical reservoir in Brazilian semiarid. Acta Limnologica Brasiliensia, 2018, vol. 30, e107.

Abstract: Aim: To evaluate the impact of a biomanipulation experiment on the feeding of fish species from a neotropical semiarid reservoir, before and after the removal of the exotic species Oreochromis niloticus. Methods: The values of Food Index were analyzed for six species: Oreochromis niloticus, Prochilodus brevis Steindachner,1875, Hypostomus cf. paparie Fowler,1941, Hoplias gr. malabaricus Bloch,1794, Astyanax bimaculatus Linnaeus, 1758 and Leporinus piau Fowler,194. All data were obtained in two periods, before of the removal O. niloticus (May 2012 to January 2013) and after its removal (April 2013 to November 2013). The Morisita-Horn index was used to evaluate the feeding similarity among the six species and determine trophic categories (insectivorous, omnivorous, iliophaga and piscivora). To establish the probable variations due the presence of $O$. niloticus species, the Food Index of the six species was used in a Bray-Curtis similarity matrix. Through the Non-metric Multidimensional Scaling (NMDS) we could not observe any differences among items consumed by different species. The Canonical Correspondence Analysis (CCA) was used to assay the influence of environmental variables on the dietary, from the Food Index data. Results: All species were classified in four trophic categories that do not shown any variation among the formed groups during studied periods. After the removal of Nile tilapia some species showed changes in food items, according to NMDS. The CCA indicated low association among the monthly Food Index of species and the environmental changes. Conclusion: The process of biomanipulation on the Ecological Station from Serra Negra reservoir, which compares the dietaries from five local species before and after removal of exotic species Oreochromis niloticus, resulted in modification of dietary composition from three of five studied species.

Keywords: biomanipulation; fishes; semiarid; diet.

Resumo: Objetivo: Avaliar o impacto de um experimento de biomanipulação na alimentação das espécies da ictiofauna de um reservatório do semiárido neotropical, antes e após a remoção da espécie exótica Oreochromis niloticus. Métodos: Os dados foram amostrados em dois períodos, antes da remoção da espécie (maio de 2012 a janeiro de 2013) e após a remoção (abril de 2013 a novembro de 2013). 
Foram analisadas os valores do Índice Alimentar de seis espécies: Oreochromis niloticus, Prochilodus brevis Steindachner,1875, Hypostomus cf. paparie Fowler,1941, Hoplias gr. malabaricus Bloch,1794, Astyanax bimaculatus Linnaeus, 1758 e Leporinus piau Fowler,194. O índice de Morisita-Horn foi usado para avaliar a similaridade alimentar entre as espécies e estabelecer categorias tróficas (insetívora, onívora, detritívora/iliófaga e piscívora). Para avaliar as possíveis variações devido à presença da espécie $O$. niloticus, foi utilizado o Índice Alimentar das espécies numa matriz de similaridade de Bray-Curtis, usando a análise de ordenação (NMDS), a Análise de Correspondência Canônica (CCA) avaliou se houve influência das variáveis ambientais na dieta, a partir dos dados do Índice Alimentar. Resultados: As espécies foram enquadradas em quatro categorias tróficas que não demonstraram variação nos grupos formados entre os períodos estudados. Após a remoção da tilápia algumas espécies apresentaram mudanças em itens alimentares, segundo a análise de ordenação (NMDS). A Análise de Correspondência Canônica indicou uma baixa associação entre os dados do Índice Alimentar mensal das espécies e as variáveis ambientais. Conclusão: $\mathrm{O}$ processo de biomanipulação no reservatório da Estação Ecológica de Serra Negra, visando comparar as dietas de cinco espécies nativas antes e após a remoção da espécie exótica Oreochromis niloticus, resultou em alteração na composição da dieta de três das cinco espécies estudadas.

Palavras-chave: biomanipulação; peixes; semiárido; dieta.

\section{Introduction}

The introduction of exotic species may contribute to negative environmental changes, which is considered as a threat to the conservation of biological diversity (Pyšek \& Richardson, 2010) and one of the major problems in the conservation of freshwater fish (Cucherousset et al., 2012).

The Nile tilapia (Oreochromis niloticus Linnaeus, 1758), for example, has been causing changes in aquatic environments (Attayde et al., 2007; 2011). For being a rustic species, it tolerates a wide variation of abiotic parameters, such as temperature, ammonia, dissolved oxygen, and shows a high reproductive rate (Kolar \& Lodge, 2002). These characteristics, combined with general eating habits (Attayde et al., 2007) and aggressive and territorial behavior, favor the competition for environmental resources, which can drastically alter the local biota (Barreto et al, 2011), explaining in parts its invading potential (Kolar \& Lodge, 2002).

Results of the introduction range from the simple establishment of an introduced population to the complete community dominance, which may include, among several effects, reduction of native species population or even local extinctions (Agostinho et al., 2003). In environments with extreme temperature conditions and water shortages, it is possible that some species present changes in their eating behavior, mainly due to changes in the availability of food resources and the species plasticity in order to explore new resources.

Considering the hypothesis that exotic species can modify the eating habits of ichthyofauna in the ecosystem, the objective of this study was to evaluate the impact of a biomanipulation experiment on the feeding habits of the ichthyofauna species from a neotropical semiarid reservoir, before and after the removal of the exotic species Oreochromis niloticus. This study is necessary to understand how introduced species influence the use of food items by trophic groups of fish in a semiarid region. Therefore, the results obtained will be useful in studies on the ecological roles of exotic species in semiarid aquatic ecosystems.

\section{Materials and Methods}

\subsection{Study area and sampling}

The study was conducted at the Estação Ecológica do Seridó (ESEC-Seridó), a permanent preservation area, belonging to the Brazilian Institute of Environment and Renewable Natural Resources (IBAMA). The ESEC reservoir has 1166 ha and it is located in the municipality of Serra Negra do Norte, south of Rio Grande do Norte state $\left(6^{\circ} 35^{\prime} \mathrm{S}, 37^{\circ} 20^{\prime} \mathrm{W}\right)$, in one of the driest regions of the semiarid northeastern Brazil, denominated regionally as Seridó (Figure 1).

Samples were collected monthly from May 2012 to November 2013. Before the biomanipulation experiment, nine collections were performed (May 2012 to January 2013) and after that, eight collections. (April to November 2013). In each month, the fish were captured using two batteries, with 11 fishing nets each, with meshes varying between $12 \mathrm{~mm}$ and $70 \mathrm{~mm}$, distance between adjacent nodes, with heights ranging from $1.20 \mathrm{~m}$ to $2.70 \mathrm{~m}$ and length of $50 \mathrm{~m}$, distributed between the entrance and dam environments (Figure 1). Capture proceeded for a period of 12 hours with two fish removal: twilight and dawn. In addition, information on the following abiotic 


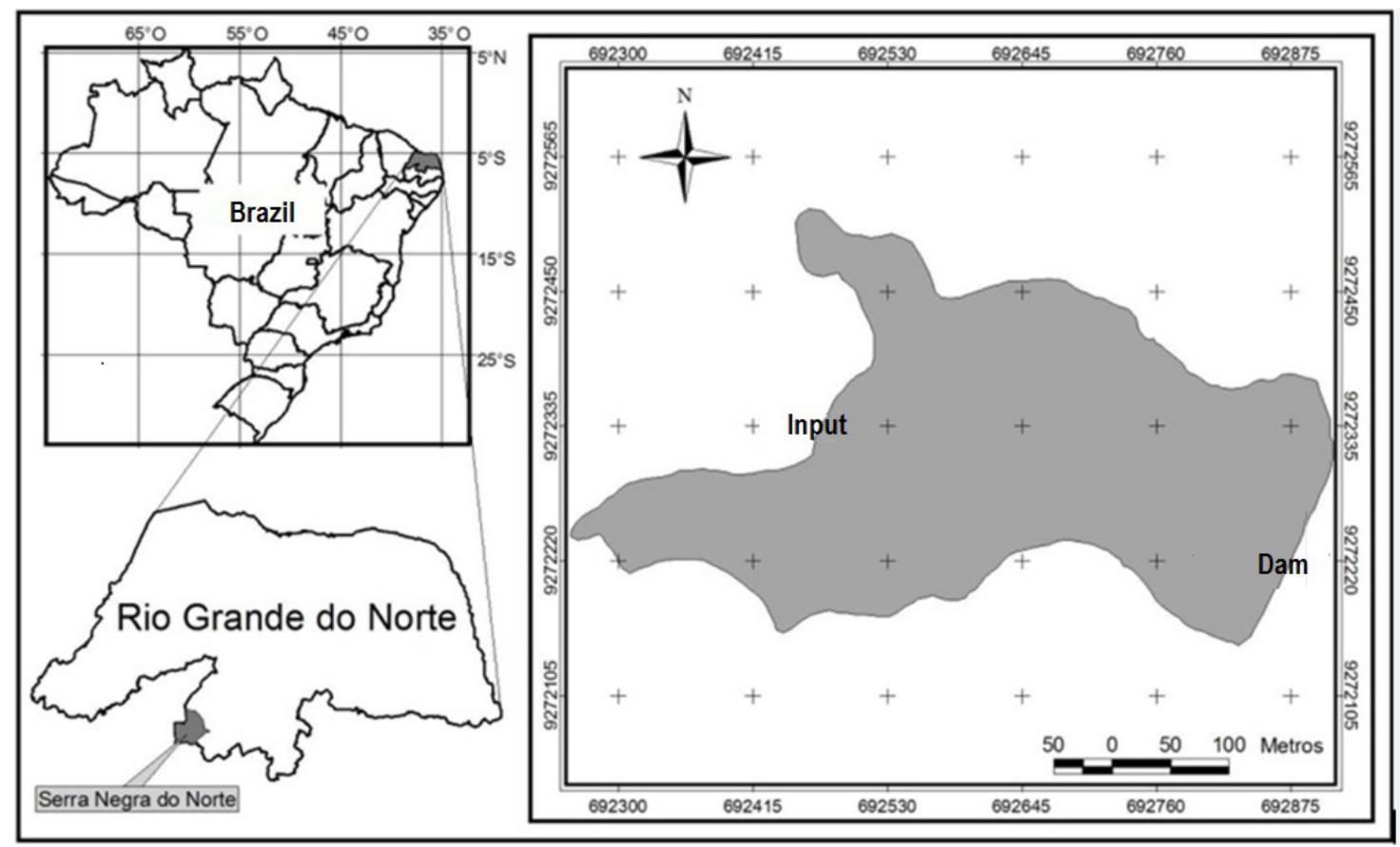

Figure 1. Location of the Estação Ecológica do Seridó (ESEC-Seridó), Serra Negra, Rio Grande do Norte, Brazil and sampling points (entrance and dam).

factors was collected: dissolved oxygen, turbidity, water temperature, $\mathrm{pH}$, and electrical conductivity using a multiparameter probe. The rainfall data were obtained from the Agricultural Research Corporation (EMPARN, 2014) in the municipality of Serra Negra - RN.

\subsection{Biomanipulation process}

The biomanipulation in the weir occurred with the use of dragging net, in February and March of 2013, where a total of 767 individuals of Oreochromis niloticus were captured, totaling $456.00 \mathrm{~kg}$. In addition, 22,000 individuals were collected from Prochilodus brevis Steindachner, 1875 , totaling $5,060.00 \mathrm{~kg}, 1,600$ individuals from Leporinus piau Fowler, 1941, totaling $240.00 \mathrm{~kg}$ and 92 individuals from Hoplias gr. malabaricus Bloch, 1794 , totaling $40.00 \mathrm{~kg}$.

The fish were transported to the laboratory where they were identified at the species level, according to specialized bibliography (Rosa et al., 2003). Then, they were submitted to biometrics, which generated data referring to the standard and total lengths $(\mathrm{mm})$ and the total weight $(\mathrm{g})$. The stomachs or intestines were removed, fixed in $10 \%$ formaldehyde and conditioned in $70 \%$ alcohol for later analysis. For stomachs removed the degree of stomach repletion was visually estimated, in a scale that can vary from 0 to 3 (Braga, 1999).
Only those species with stomachs with a degree of stomach filling greater than 1 are used for the study of feeding. For Loricariidae, whose gut is used for the study of the diet, the analysis was made from the content present in the anterior portion of the lumen, which corresponds to $10 \%$ of the total length of the intestine (Peretti \& Andrian, 2004; Oliveira et al., 2016).

\subsection{Analysis of stomach contents}

After the stomach contents of some species (and the intestinal contents of the Loricariidae family specimens) were removed, they were analyzed under a stereoscopic and optical microscope, and the items were identified to the lowest possible taxonomic level using specialized literature: (McCafferty, 1981; Needham \& Needham, 1982; Merritt \& Cummins, 1996; Bicudo \& Menezes, 2006).

The volume of the items was obtained through the liquid displacement in a graduated cylinder or through a millimeter plate (transformed in $\mathrm{ml}$ ) (Hellawel \& Abel, 1971). For Prochilodontidae and Loricariidae the total volume of the food content was obtained, which was suspended in $70 \%$ alcohol and part of the solution removed was investigated under a microscopic slide. For each individual, three slides were verified, and their items, after identification, were estimated visually 
in percentage. The percentages associated with the total volume correspond to the volume of the item. (Peretti \& Andrian, 2004; Oliveira et al., 2016). Then, occurrence and volume frequencies, whose association gave rise to the calculation of Feeding Index (IAi) (Kawakami \& Vazzoler, 1980), were calculated (Zavala-Camin, 1996) in percentage: $\mathrm{IAi}=$ Fo. Fv $/ \Sigma($ Fo Fv) x 100. Where: $\mathrm{IAi}=$ index of alimentary importance; Fo = frequency of occurrence; $\mathrm{Fv}=$ volumetric frequency.

\subsection{Data analysis}

In order to evaluate the food similarity among the species and establish the trophic categories, the IAi values of each species, before and after the biomanipulation experiment, were used in two matrices of similarity using the Morisita-Horn index, through the Non-Hierarchical Aggregate analysis based on the UPGMA method. Afterwards, the similarity matrix was compared with a cophenetic matrix in order to evaluate the consistency of the clustering pattern, and values close to the unit indicate better representation (Cruz \& Carneiro, 2003).

In order to verify if the biomanipulation influences the trophic structure, the volume value of the alimentary items of each species was used in a similarity matrix, using the Bray-Curtis similarity coefficient. The results of each procedure were used in a Non-Metric Multidimensional Scaling (NMDS) analysis to evaluate the utilization of food resources of the species before and after removal. In order to verify variations in the diet of the species, Permutational Multivariate Analysis of
Variance (PERMANOVA) were performed using the Bray-Curtis similarity index.

Canonical Correspondence Analysis (CCA) was used to evaluate whether the environmental variables in the diet were influenced by the environmental and species Alimentary Index data (IAi) determined in each sample, the significance of the axes was tested through Monte Carlo simulation (with 9999 permutations). Statistical analysis was performed using PAST statistical software (Paleontological Statistic), version 3.14. (Hammer et al., 2017).

\section{Results}

The Estação Ecológica do Seridó presented a characteristic seasonal variation of the semiarid region, with irregular precipitations. With respect to some physical-chemical variables of water, it is generally a basic $\mathrm{pH}$ environment, dissolved oxygen with values often below $7 \mathrm{mg} / \mathrm{L}$ and temperature fluctuating around $26^{\circ} \mathrm{C}$ to $29^{\circ} \mathrm{C}$. The temperature and turbidity were proportional to the rainfall, being the highest values in the rainy season (Figure 2).

A total of 2,084 individuals were collected (1,200 before and 884 after tilapia removal), of which a total of 846 stomachs had their contents analyzed. The captured fish were distributed in six species belonging to six families and three orders, five being native species and one exotic (Table 1).

Other species were captured during the study: Cichlassoma orientale Kullander, 1983, Leporinus elongatus Valenciennes, 1850, and Leporinus taeniatus Lütken, 1875, but those showing a small number of individuals (less than 10) were not considered for the stomach contents' analysis.
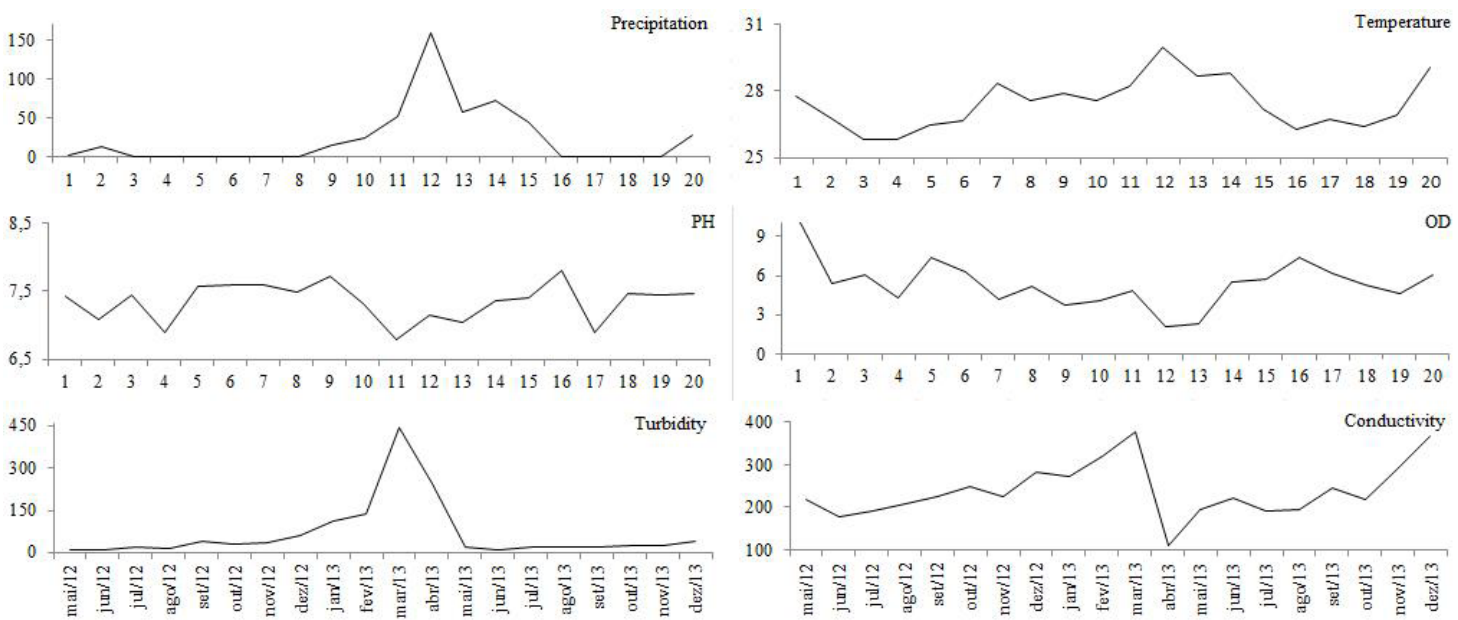

Figure 2. Precipitation data $(\mathrm{mm})$, water temperature $\left({ }^{\circ} \mathrm{C}\right), \mathrm{pH}$, conductivity $(\mu \mathrm{S} . \mathrm{cm}-1)$, dissolved oxygen $(\mathrm{OD})(\mathrm{mg} / \mathrm{L})$, turbidity (UNT) collected from May 2012 to December 2013, at the Estação Ecológica do Seridó (ESEC-Seridó), Serra Negra, Rio Grande do Norte, Brazil. 
Table 1. Species of fish studied at the Estação Ecológica do Seridó (ESEC-Seridó), Serra Negra, Rio Grande do Norte, Brazil, before and after biomanipulation.

\begin{tabular}{|c|c|c|c|c|c|c|c|c|}
\hline \multirow{2}{*}{ TAXONOMIC GROUP } & \multicolumn{4}{|c|}{ Before Removal } & \multicolumn{4}{|c|}{ After removal } \\
\hline & $\mathbf{N}$ & $\mathrm{N}(\%)$ & $E$ & $E(\%)$ & $\mathbf{N}$ & $\mathrm{N}(\%)$ & $E$ & $E(\%)$ \\
\hline \multicolumn{9}{|l|}{ CHARACIFORMES } \\
\hline \multicolumn{9}{|l|}{ Prochilodontidae } \\
\hline Prochilodus brevis (Steindachner, 1875) & 199 & 16.58 & 158 & 32.51 & 171 & 19.34 & 125 & 34.72 \\
\hline \multicolumn{9}{|l|}{ Characidae } \\
\hline Astyanax bimaculatus (Linnaeus, 1758) & 108 & 9 & 21 & 4.32 & 286 & 32.35 & 94 & 26.11 \\
\hline \multicolumn{9}{|l|}{ Anostomidae } \\
\hline Leporinus piau (Fowler, 1941) & 413 & 34.4 & 118 & 24.27 & 99 & 11.20 & 36 & 10 \\
\hline \multicolumn{9}{|l|}{ Erytrinidae } \\
\hline Hoplias gr. malabaricus (Bloch, 1794) & 405 & 33.75 & 114 & 23.45 & 220 & 24.89 & 56 & 15.55 \\
\hline \multicolumn{9}{|l|}{ SILURIFORMES } \\
\hline \multicolumn{9}{|l|}{ Loricariidae } \\
\hline Hypostomus cf. paparie (Fowler, 1941) & 63 & 5.25 & 67 & 13.78 & 78 & 8.82 & 47 & 13.05 \\
\hline \multicolumn{9}{|l|}{ PERCIFORMES } \\
\hline \multicolumn{9}{|l|}{ Cichlidae } \\
\hline *Oreochromis niloticus (Linnaeus, 1758) & 12 & 1 & 8 & 1.65 & 30 & 3.39 & 2 & 0.55 \\
\hline TOTAL & 1,200 & 100 & 486 & 100 & 884 & 100 & 360 & 100 \\
\hline
\end{tabular}

*Exotic species; $\mathrm{N}$ - number of individuals collected; $\mathrm{N}(\%)$ - percentage of individuals collected; $\mathrm{E}$ - number of analyzed stomachs; $\mathrm{E}(\%)$ - percentage of stomachs analyzed.

The order with the largest number of species was Characiformes, with four native species; the order Siluriformes presented only one native species and the order Perciformes only one exotic species of the family Cichlidae. Among the families found, are Prochilodontidae, Erytrinidae, Characidae, Anostomidae and Loricariidae with only one representation of each species and the family Cichlidae with one exotic species.

In general, the diet of the species was composed of nine items, which presented different origins: animal, vegetable, dendrites and sediments. The ones originated from animal resources consisted of Insects (Diptera, Ephemeroptera, Hymenoptera, Plecoptera, Lepidoptera and remains of unidentified insects); Fish (whole, fishbones or scales); Shrimp (whole or parts); Zooplankton (Protozoa and Microcrustaceans); Other invertebrates, represented by groups of invertebrates that demonstrated low values of IAi (mollusks, annelids, arachnids).

The vegetable items included plant debris, seeds, and Phytoplankton (Cyanophyceae, Bacillariophyta, Chlorophyceae, Zygnematophyceae). It were also described, detritus (organic material at different stages of decomposition) and sediment (fine and particulate material constituted mainly by inorganic matter - sand or silt). Finally, digested plant or animal material (resources that were not possible to identify in the other categories due the advanced degree of digestion).
Data from the Feeding Index (IAI) of the species, before and after removal of tilapia, showed that species did not change their eating habits, although the prevalence of some items decreased, with low consumption values of vegetal items, fish, and insects being observed for some species after the biomanipulation process (Table 2).

Data from the Feeding Index (IAi) of the species, before and after the biomanipulation, were used for the analysis of food similarity, being the species framed in four trophic categories that did not show variation in the groups formed between the two periods studied (Figure 3).

The species of each trophic category showed consumption of one or more dominant alimentary items, with three species classified as detritivorous/iliophagous (O. niloticus, $P$. brevis and $H$. cf. paparie), for presenting in their diet a predominance of detritus/sediment, phytoplankton and zooplankton; one as omnivorous (L. piau), for showing a consumption of items of animal and plant origin in a reasonably distributed form; one as insectivorous (A. bimaculatus), for consuming mainly insects; and one species as piscivora $(H$. gr. malabaricus), for having a fish predominating diet. There were variations in the use of food resources of the species studied before and after tilapia removal (Figure 4).

There was a change in the diet composition of Astyanax bimaculatus after the event of 
exotic species removal (NMDS stress: 0.25; PERMANOVA $\mathrm{p}=0.0001$ ), mainly with the variation from a diet composed of Ephemeroptera order insects, to Diptera (Table 2). Leporinus piau also showed changes in the diet (NMDS stress: 0.55; PERMANOVA $\mathrm{p}=0.0001$ ), although it presented as omnivorous, prior to the removal event it utilized mainly animal resources and, after the removal, it showed a preference for vegetal resources. (Table 2). Fish was the preferred item in the Hoplias gr. malabaricus diet before and after removal, however this species also ingested some accidental items such as vegetables, insects and other invertebrates in a small quantity (NMDS stress: 0.08, PERMANOVA $\mathrm{p}=0.0001)($ Table 2$)$. There were changes in the Hypostomus cf. paparie diet (NMDS stress: 0.15, PERMANOVA $\mathrm{p}=0.0001$ ), with an increase in algae, sediment and detritus consumption after tilapia removal (Table 2). Prochilodus brevis also had alterations in diet

Table 2. Feeding Index (IAi) of fish species studied at the Estação Ecológica do Seridó (ESEC-Seridó), Serra Negra, Rio Grande do Norte, Brazil, before and after the biomanipulation.

\begin{tabular}{|c|c|c|c|c|c|c|c|c|c|}
\hline & \multicolumn{9}{|c|}{ Before the biomanipulation experiment } \\
\hline & $\mathrm{D} / \mathrm{S}$ & Veg. & Fit. & Zoo. & Ins. & Pei. & $\mathrm{O} / \mathrm{I}$ & MV & MA \\
\hline Astyanax bimaculatus & & 4.85 & & 0.37 & 67.43 & 20.48 & & & \\
\hline Hoplias gr. malabaricus & & 0.18 & & & 0.41 & 99.60 & & & \\
\hline Leporinus piau & 1.32 & 13.66 & & 0.19 & 21.55 & 0.38 & 0.97 & 9.18 & 43.92 \\
\hline Prochilodus brevis & 92.52 & & 6.98 & 0.56 & & & & & \\
\hline Hypostomus c.f paparie & 85.16 & & 14.15 & 0.76 & & & & & \\
\hline \multirow[t]{3}{*}{ Oreochromis niloticus } & 49.26 & 27.13 & 11.42 & & & & & & \\
\hline & \multicolumn{9}{|c|}{ After the biomanipulation experiment } \\
\hline & $\mathrm{D} / \mathrm{S}$ & Veg. & Fit. & Zoo. & Ins. & Pei. & $\mathrm{O} / \mathrm{I}$ & MV & MA \\
\hline Astyanax bimaculatus & & 9.46 & & 2.94 & 73.64 & 10.52 & 0.75 & & \\
\hline Hoplias gr. malabaricus & & 0.25 & & & 0.24 & 98.67 & 0.48 & & \\
\hline Leporinus piau & 0.19 & 33.68 & 0.25 & 1.37 & 6.55 & 0.16 & 0.19 & 20.54 & 21.46 \\
\hline Prochilodus brevis & 79.69 & & 19.71 & 0.62 & & & & & \\
\hline Hypostomus c.f paparie & 72.27 & & 26.45 & 1.18 & & & 0.74 & & \\
\hline Oreochromis niloticus & 51.25 & 12.76 & 25.51 & & & & & & \\
\hline
\end{tabular}

D/S - Detritus and Sediment; Veg. - Vegetable; Fit. - Phytoplankton; Zoo. - Zooplankton; Ins. - Insects; Pei. - Fish; O/I - Other Invertebrates; MV - Digested plant material; MA - Digested animal material. Highlighted the dominant food items.
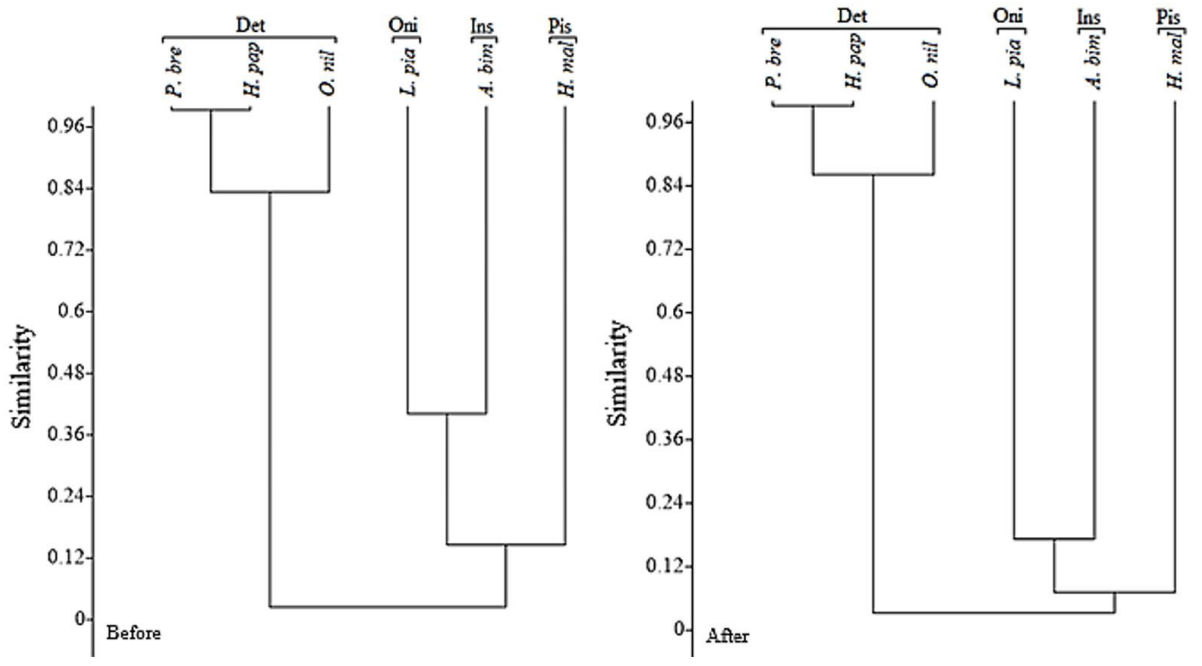

Figure 3. Food similarity dendrogram from the Alimentary Index (IAi) of the studied fish species, before (Cophen. corr.: 0.98) and after (Cophen. corr.: 0.98) the biomanipulation experiment at the Estaçáo Ecológica do Seridó (ESEC-Seridó), Serra Negra, Rio Grande do Norte, Brazil. 

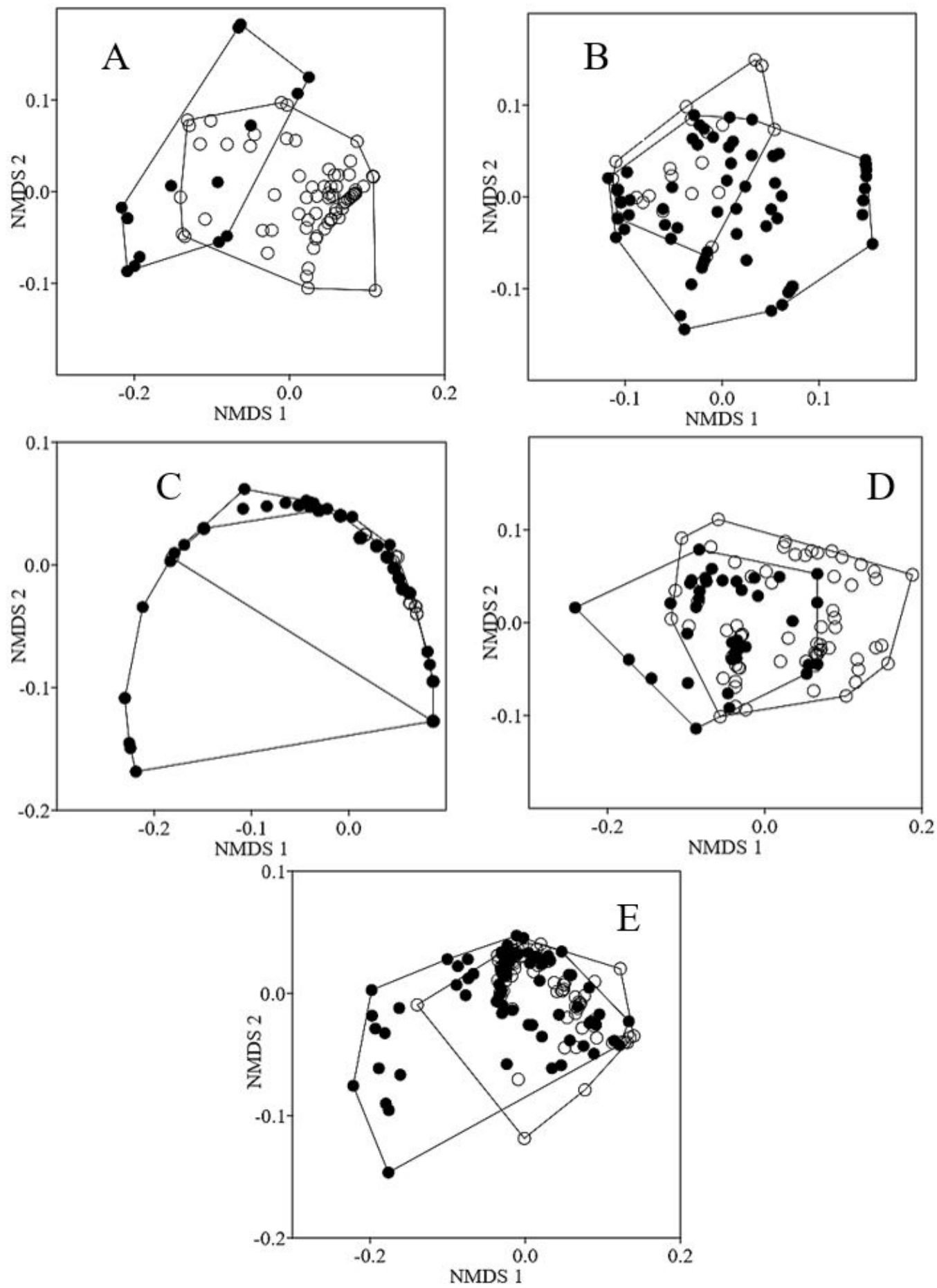

Figure 4. Graphical representation of the first two axes of the NMDS, showing the variation in the consumption of food resources of the studied fish species, - before and after the biomanipulation experiment, at the Estação Ecológica do Seridó (ESEC-Seridó), Serra Negra, Rio Grande do Norte, Brazil. A - Astyanax bimaculatus Linnaeus,1758; B - Leporinus pian Fowler,1941; C - Hoplias gr. malabaricus Bloch,1794; D - Hypostomus cf. paparie Fowler,1941; E-Prochilodus brevis Steindachner, 1875.

(NMDS stress: 0.21, PERMANOVA p = 0.0001), consuming more protozoa after removal (Table 2).

The Canonic Correspondence Analysis (CCA, Figure 5) indicated a low association between the monthly Feeding Index (IAi) data of the species and the environmental variables for the months of sample collecting, with the consumption of food resources being determinant in the 

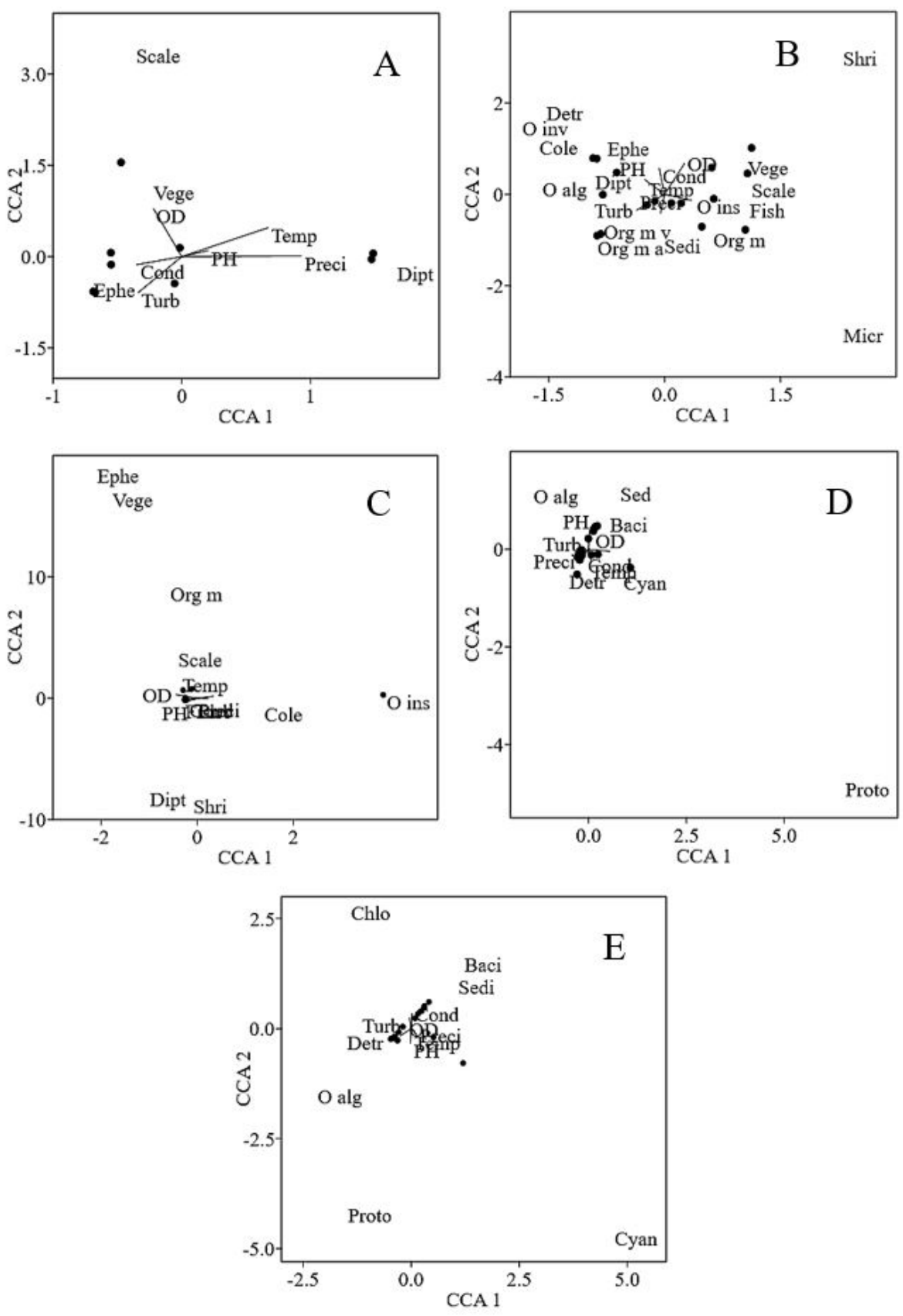

Figure 5. Canonical Correspondence Analysis (CCA) between environmental variables (rainfall, temperature, $\mathrm{pH}$, dissolved oxygen, conductivity and turbidity) and the Alimentary Index (IAI - per month collection) at the Estação Ecológica do Seridó (ESEC-Seridó), Serra Negra, Rio Grande do Norte, Brazil. A - Astyanax bimaculatus Linnaeus, 1758; B - Leporinus pian Fowler, 1941; C - Hoplias gr. malabaricus Bloch, 1794; D - Hypostomus cf.paparie Fowler,1941; E - Prochilodus brevis Steindachner, 1875.

individuals distribution over the months, therefore, environmental variables do not influence the type of items consumed by the species (Table 3 ).

\section{Discussion}

The results of this research have shown that the introduction of the exotic species Oreochromis niloticus, at the Seridó Ecological Station (ESEC-RN) weir, influenced changes in the diet of some species of the ichthyofauna. Some studies show that the introduction of $O$. niloticus alters the composition of the native ichthyofauna, and it compromises local artisanal fishing (Attayde et al., 2011; Novaes \& Carvalho, 2011).

Tilapia, being an exotic species, combined with its generalist eating habit (Attayde et al., 2007) 
Table 3. Statistical Summary of Canonical Correspondence Analysis of the data from the Alimentary Index of species and environmental variables for months of collection at the Estação Ecológica do Seridó (ESEC-Seridó), Serra Negra, Rio Grande do Norte, Brazil.

\begin{tabular}{ccccc}
\hline Statistical Summary & Axis & \% Axis Explanation & $\begin{array}{c}\text { Correlation } \\
\text { Species I } \\
\text { Environment }\end{array}$ & Monte Carlo "p" \\
\hline Figure 5. A & 1 & 60.12 & 0.627 & 0.16 \\
Figure 5. B & 2 & 31.97 & 0.334 & 0.47 \\
& 1 & 34.86 & 0.357 & 0.65 \\
Figure 5. C & 2 & 25.14 & 0.257 & 0.55 \\
& 1 & 64.11 & 0.1042 & 0.13 \\
Figure 5. D & 2 & 34.76 & 0.056 & 0.02 \\
& 1 & 49.46 & 0.032 & 0.82 \\
Figure 5. E & 2 & 32.99 & 0.021 & 0.40 \\
& 1 & 60.63 & 0.085 & 0.44 \\
\hline
\end{tabular}

and aggressive and territorial behavior, favors its competition for environmental resources, which can drastically alter the local biota (Barreto et al., 2011), partly explaining its invading potential (Kolar \& Lodge, 2002). Changes in the native species trophic guilds were expected, but according to the Food Similarity Index, the number of guilds did not vary during the studied period. Abelha et al. (2001) in a review on food plasticity showed that the feeding of the ichthyofauna can undergo spatial and temporal changes, considering that different places and periods have different abiotic conditions, but this change in the alimentary spectrum does not imply changes in the ecological function of the species. Thus, our results corroborate with the assembly rule proposed by Fox (1987) and Fox \& Brown (1993), which is based on functional groups and suggest that new species added to communities tend to fill existing functional groups.

From the obtained results, we observed that the species studied in the ESEC, explored, in different ways, the food items before and after the tilapia withdrawal without modifying the trophic groups present. The predominance of insectivorous species in the analyzed environments can be attributed to the fact that several species of insects do not have very strong environmental restrictions. In the case of the species Astyanax bimaculatus, there was a replacement of insects from Ephemeroptera order for insects of the order Diptera, after the removal of tilapia. In the case of the species Hypostomus cfpapariae, there was an increase in the consumption of algae after the removal of tilapia. This fact may have occurred due to the decrease in water turbidity after the removal of the exotic species. The availability of underwater light is a key factor in the regulation of phytoplankton dynamics (Zohary \& Ostrovsky, 2011). Costa et al. (2016), on his research, performed at the ESEC Lake, noticed an immediate increase of phytoplankton after the fish removal. Abelha et al. (2001) state that fish feeding may undergo temporal changes, but this modification in the food spectrum does not imply changes in the ecological function of the species. Thus, in general, the food sources of their environment can be divided with other species, being the intensity of negative impacts dependent on biotic and abiotic factors, since there may be coexistence between native and exotic species, if certain specific conditions are met (Ribeiro \& Leunda, 2012).

The Canonical Correspondence Analysis evidenced a low association between the data from Alimentary Index (IAi) of the species and environmental variables, corroborating the hypothesis of the research, which affirms that the introduction of the exotic species influences the diet of the local ichthyofauna.

The process of biomanipulation in the reservoir of the Estação Ecológica de Serra Negra aiming to compare the diets of five native species before and after the removal of the exotic species Oreochromis niloticus resulted in diet composition changing in three of the five species studied: Astianax bimaculatus, Leporinus piau and Hypostomus paparie and did not influence the diet composition of the two other species: Hoplias malabaricus and Prochilodus brevis.

\section{Acknowledgements}

We would like to express our gratitude to the undergraduate students from the Fishing Engineering course (UFERSA) and from the Biological Sciences course (UERN), and also to CNPq for the financial aid provided. 


\section{References}

ABELHA, M.C.F., AgOsTinho, A.A. and GOULART, E. Plasticidade trófica em peixes de água doce. Acta Scientiarum, 2001, 23(2), 425-434.

AGOSTINHO, A.A., GOMES, L.C., SUZUKI, H.I. and JÚLIO JÚNIOR, H.F. Migratory fishes of the upper Paraná River basin, Brazil. Migratory fishes of South America. In: J. CAROLSFELD, B. HARVEY, C. ROSS and A. BAER, eds. Migratory fishes of South America: biology, fisheries and conservation status. Ottawa: World Fisheries Trust, The World Bank, International Developmente Research Centre, 2003. pp. 19-98.

ATTAYDE, J.L., BRASIL, J. and MENESCAL, R.A. Impacts of introducing Nile tilapia on the fisheries of a tropical reservoir in North-eastern Brazil. Fisheries Management and Ecology, 2011, 18(6), 437-443. http://dx.doi.org/10.1111/j.13652400.2011.00796.x.

ATTAYDE, J.L., OKUN, N., BRASIL, J., MENEZES, R. and MESQUITA, P. Impactos da introduçáo da tilápia do Nilo, Oreochromis niloticus, sobre a estrutura trófica dos ecossistemas aquáticos do bioma Caatinga. Oecologia Brasiliensis, 2007, 3(03), 450461. http://dx.doi.org/10.4257/oeco.2007.1103.13.

BARRETO, R.E., CARVALHO, G.G. and VOLPATO, G.L. The aggressive behavior of Nile tilapia introduced into novel environments with variation in enrichment. Zoology (Jena, Germany), 2011, 114(1), 53-57. http://dx.doi.org/10.1016/j. zool.2010.09.001. PMid:21196103.

BICUDO, C.E.M. and MENEZES, M. Gênero de algas de águas continentais do Brasil: chave para identificação e descrição. 2. ed. São Carlos: Editora Rima, 2006.

BRAGA, F.M.S. O grau de preferência alimentar: um método qualitativo e quantitativo para o estudo do conteúdo estomacal de peixes. Acta Scientiarum, 1999, 21(2), 291-295.

COSTA, M.R.A., ATTAYDE, J.L. and BECKER, V. Effects of water level reduction on the dynamics of phytoplankton functional groups in tropical semiarid shallow lakes. Hydrobiologia, 2016, 778(1), 7589. http://dx.doi.org/10.1007/s10750-015-2593-6.

CRUZ, C.D. and CARNEIRO, P.C.S. Modelos biométricos aplicados ao melhoramento genético. Viçosa: UFV, 2003.585 p.

CUCHEROUSSET, J., BLANCHET, S. and OLDEN, J.D. Non-native species promote the trophic dispersion of food webs. Frontiers in Ecology and the Environment, 2012, 10(8), 406-407. http://dx.doi. org/10.1890/12.WB.018.

EMPRESA DE PESQUISA AGROPECUÁRIA DO RIO GRANDE DO NORTE S/A - EMPARN. Meteorologia Relatórios 2013 e 2014 [online]. Parnamirim: EMPARN, 2014 [viewed 07 Dec.
2014]. Available from: http://www.emparn.rn.gov. br/Index.asp

FOX, B.J. and BROWN, J.H. Assembly rules for functional groups in North American desert rodent communities. Oikos, 1993, 67(2), 358-370. http:// dx.doi.org/10.2307/3545483.

FOX, B.J. Species assembly and the evolution of community structure. Evolutionary Ecology, 1987, 1(3), 201-213. http://dx.doi.org/10.1007/ BF02067551.

HAMMER, Ø., HARPER, D.A.T. and RYAN, P.D. PAST: Paleontological Statistics Software Package for education and data analysis. Palaeontolia Electronica 4, 2017.

HELLAWELL, J.M. and ABEL, R. A rapid volumetric method for the analysis of the food of fishes. Journal of Fish Biology, 1971, (3), 19-37.

KAWAKAMI, E. and VAZZOLER, G. Método gráfico e estimativa de índice alimentar aplicado no estudo de alimentação de peixes. Boletim do Instituto Oceanográfico, 1980, 29(2), 205-207. http://dx.doi. org/10.1590/S0373-55241980000200043.

KOLAR, C.S. and LODGE, D.M. Ecological predictions and risk assessment for alien fishes in north america. Science, 2002, 298(5596), 1233-1236. http://dx.doi. org/10.1126/science.1075753. PMid:12424378.

MCCAFFERTY, W.P. Aquatic entomology. Boston: Jones and Barlett Publisher, 1981. 448 p.

MERRITT, R.W. and CUMMINS, K.W. An introduction to the aquatic insects of North America. Dubuque: Kendall/Hunt, 1996.

NEEDHAM, J.G. and NEEDHAM, P.R. Guia para el estudio de los seres vivos de las aguas dulces. Barcelona: Editora Reverté S.A., 1982.

NOVAES, J.L.C. and CARVALHO, E.D. Artisanal fisheries in a Brazilian hypereutrophic reservoir: Barra Bonita reservoir, middle Tietê river. Brazilian Journal of Biology = Revista Brasileira de Biologia, 2011, 71(4), 821-832. http://dx.doi.org/10.1590/ S1519-69842011000500003.

OLIVEIRA, J.F., MORAES-SEGUNDO, A.L.N., NOVAES, J.L.C., COSTA, R.S., FRANÇA, J.S. and PERETTI, D. Estrutura trófica da ictiofauna em um reservatório do semiárido brasileiro. Iheringia. Série Zoologia, 2016, 106(0), 1-9. http://dx.doi. org/10.1590/1678-4766e2016001.

PERETTI, D. and ANDRIAN, I.F. Trophic structure of fish assembleges in five permanent lagoons of the high Paraná River floodpain, BrazilEnvironmental. Biology of Fishes, 2004, 71(1), 95-103. http://dx.doi. org/10.1023/B:EBFI.0000043155.76741.a1.

PYŠEK, P. and RICHARDSON, D.M. Invasive species, environmental change and management, and health. Annual Review of Environment and Resources, 2010, 35(1), 25-55. http://dx.doi.org/10.1146/annurevenviron-033009-095548. 
RIBEIRO, F. and LEUNDA, P.M. Non-native fish impacts on Mediterranean freshwater ecosystems: current knowledge and research needs. Fisheries Management and Ecology, 2012, 19(2), 142-156. http://dx.doi. org/10.1111/j.1365-2400.2011.00842.x.

ROSA, R.S., MENEZES, N.A., BRISTSKI, H.A.W.J.E., COSTA, M. and GROTH, F. Diversidade, padróes de distribuição e conservaçáo dos peixes da caatinga. In: I.R. Leal, M. Tabarelli and J.M.C. Silva, eds. Ecologia e Conservação da Caatinga. Recife: Editora da UFPE, 2003. p. 135-180.
ZAVALA-CAMIN, L.A. Introdução aos estudos sobre alimentação natural em peixes. Maringa: EDUEM, 1996. 129 p.

ZOHARY, T. and OSTROVSKY, I. Ecological impacts of excessive water level fluctuations in stratified freshwater lakes. Inland Waters, 2011, 1(1), 47-59. http://dx.doi.org/10.5268/IW-1.1.406.

Received: 13 March 2017 Accepted: 31 October 2017 